\title{
Теоретико-методичні основи професійно-прикладної фізичної підготовки студентів мистецьких спеціальностей
}

\author{
Інна Асаулюк', Віталій Кашуба
}

1 Вінницький державний педагогічний університет ім. М. Коцюбинського, Вінниця, Україна

${ }_{2}^{2}$ Національний університет фрізичного виховання і спорту України, Київ, Україна

Анотація. Проблемами просресійно-прикладної фрізичної підготовки студентів різних спеціальностей закладів освіти є збереження та зміцнення здоров'я студентської молоді; потреба змістового доповнення розділу професійно-прикладної фрізичної підготовки програми з фізичного виховання з огляду на особливості умов і характер праці майбутньої професійної діяльності студентів; необхідність системного підходу до використання форм, засобів і методів підвищення рівня розвитку їхніх професійно важливих якостей. Мета. На основі теоретичного аналізу та власних досліджень науково обгрунтувати, розробити й експериментально перевірити дієвість концепції професійно-прикладної фізичної підготовки студентів спеціальності «Музичне мистецтво» для підвищення рівня їхньої готовності до просресійної діяльності. Методи. Аналіз та узагальнення науково-методичної літератури, абстрагування, контент-аналіз, тестування. Результати. Фізичне благополуччя, рівень фізичної підготовленості та фізичної активності, функціональний стан організму, прикладні навички було обрано як базові поняття, що є власними векторами під час розробки навчальних програм з прикладної професійної фізичної культури для студентів мистецьких спеціальностей. У дослідженні обґрунтовується доцільність акцентованого виховання індивідуальних фізичних і спеціальних характеристик, життєво важливих для високопродуктивної роботи майбутнього фрахівця в даній сфрері, а також набуття комплексу прикладних навичок використання засобів фізичного розвитку.

Ключові слова: фізичне виховання, прикладна професійна фізична культура, концепція, технологія, фізичний стан.

\section{Inna Asauliuk, Vitalii Kashuba}

\section{THEORETICO-METHODOLOGICAL BASES OF PROFESSIONAL AND APPLIED PHYSICAL TRAINING OF STUDENTS OF ART SPECIALTIES}

Abstract. The problems of professional and applied physical training of students of different specialties of educational institutions are the preservation and strengthening of the health of student youth; the need for substantive addition to the section of professional and applied physical training of the program of physical education with account for the peculiarities of the conditions and nature of work of future professional activities of students; the need for a systematic approach to the use of forms, means and methods to increase the development level of their professionally important qualities. Objective. Based on theoretical analysis and own research to scientifically substantiate, develop and experimentally test the effectiveness of the concept of professional and applied physical training of students majoring in «Musical Art» to increase their readiness for professional activity. Methods. Analysis and generalization of scientific and methodological literature, abstraction, content analysis, testing. Results. Physical well-being,

level of physical fitness and physical activity, functional state of the body, applied skills were chosen as basic concepts that are their own vectors in the development of curricula in applied professional physical culture for art students. The study substantiates the feasibility of focused education of individual physical and special characteristics, vital for the highly productive work of the future specialist in this field, as well as the acquisition of a set of applied skills in the use of physical development.

Keywords: physical education, applied professional physical culture, concept, technology, physical condition.

Asauliuk I., Kashuba V. Theoreticomethodological bases of professional and applied physical training of students of art specialties. Theory and Methods of Physical education and sports. 2021; 1: 37-43 DOI: 10.32652/tmfvs.2021.1.37-43
Асаулюк І., Кашуба В. Теоретикометодичні основи просресійно-прикладної фізичної підготовки студентів мистецьких спеціальностей. Теорія і методика фізичного виховання і спорту. 2021; 1: 37-43 DOI: 10.32652/tmfvs.2021.1.37-43
Вступ. Динаміка розвитку сучасного суспільства зумовлена дотриманням інноваційного вектора, до виявів якого належать науково-технічний поступ, швидка зміна технологій, трансформації в системі життєвих цілей і цінностей. Це позначається на вимогах соціуму до системи освіти [1, $4,19]$.

Науково-технічна еволюція вносить суттєві корективи у сферу виробничої діяльності фрахівців, оновлює та ускладнює вимоги до профресійно-прикладної фрізичної підготовки (ППФП) студентів, їхньої трудової діяльності [18].

Особливе місце у професійній освіті майбутніх фахівців посідає спеціальна фрізична підготовка, застосування інформаційних технологій у практиці фізичного виховання, які відкривають нові можливості для підвищення ефективності організації процесу ППФП [5, 6].

Огляд наукових джерел [4, 13, $14,20,22]$ дає підстави говорити про недостатність у науковому дискурсі досліджень, присвячених організації професійної підготовки студентів мистецьких спеціальностей.

Мета дослідження - науково обґрунтувати, розробити й експериментально перевірити дієвість концепції професійно-прикладної фрізичної підготовки студентів спеціальності «Музичне мистецтво» для підвищення рівня їхньої готовності до професійної діяльності.

Методи дослідження: аналіз та узагальнення спеціальної науковометодичної літератури, інформаційних ресурсів мережі Інтернет і передового досвіду; узагальнення нормативноправової бази, програмно-методичної документації; абстрагування, контентаналіз, конкретизація та класифікація, прогнозування; тестування теоретичних знань, педагогічне спостереження, педагогічне тестування, педагогічний експеримент, візуальний "скринінг» рівня стану біогеометричного 
профрілю постави; оцінювання рівня фрізичного здоров'я; експертне оцінювання за допомогою методу переваги (ранжування); методи математичної статистики.

Результати дослідження та їх обговорення. У дослідженні взяли участь 788 студентів Вінницького училища культури і мистецтв імені М. Д. Леонтовича, Тульчинського коледжу культури, Житомирського музичного училища імені Віктора Косенка, а саме: I курс ( $\mathrm{n}=196)$, II курс $(\mathrm{n}=200)$, III курс $(\mathrm{n}=192)$, IV курс $(\mathrm{n}=200)$.

До експерименту було залучено 40 студентів Вінницького училища культури і мистецтв імені М. Д. Леонтовича 21 юнака 16-17 років спеціалізації «оркестрові духові та ударні інструменти, народні інструменти» та розподілено їх на експериментальну (ЕГ2) (11 осіб) і контрольну групи (КГ2) (10 осіб); 19 дівчат спеціалізації «фрортепіано, оркестрові, струнні інструменти» та розподілено їх на ЕГ1 (9 осіб) і КГ1 (10 осіб). Групи було сформовано випадковим чином. Студенти на початок педагогічного експерименту не мали статистично достовірної різниці $(p>0,05)$ у показниках, які підлягали вивченню. Особи контрольних груп займалися за традиційною програмою з фізичного виховання, а експериментальних груп - за розробленою технологією підвищення професійно значущих фрізичних якостей, інтегрованою у програму з фізичної культури. Кратність і тривалість занять із фрізичного виховання в КГ та ЕГ на тиждень була однаковою (1-й семестр - 32 заняття 2-й семестр - 40 занять).

У ході констатуючого експерименту розкрито особливості мотивів та інтересів студентів мистецьких спеціальностей I-IV курсів до занять фізичною культурою і спортом [2, 26] визначено рівень теоретичних знань студентів із предмета «фрізична культура» [24], проаналізовано рівень фрізичної підготовленості, срізичної роботоздатності, функціонального стану та фрізичного здоров'я, проведено експертне оцінювання фрізичних якостей і профресійно важливих якостей студентів спеціальності «Музичне мистецтво» $[9,12]$.
Оцінювання й аналіз даних анкетування, проведеного на предмет визначення мотиваційних пріоритетів студентів мистецьких спеціальностей, слугують основою для констатації того факту, що більшість студентів вважає доцільним проведення в їхньому освітньому закладі позанавчальних занять ффізкультурно-оздоровчого спрямування [4]

У ході дослідження оцінено рівень фізичного здоров'я (РФЗ) студентів мистецьких спеціальностей і виявлено домінування середнього рівня фізичного здоров'я: у дівчат I курсу - 70,87 \%, II курсу - 62,59 \%, III та IV курсів - 58,46 \% і 59,69 \% відповідно, тоді як найбільшу кількість осіб із РФ3 «низький» спостерігали серед дівчат IV курсу -13,95\%. У юнаків I курсу - 57,97\%, II курсу -70,49\%, III та IV курсів - 75,81 \% і 73,24 \% відповідно (найбільшу кількість осіб із РФЗ «низький» виявлено серед юнаків II курсу - 3,28 \%) [4].

На основі візуального скринінгу рівня стану біогеометричного просрілю постави респондентів окреслено тенденцію до посилення негативної динаміки збільшення кількості студентів із різнотипними функціональними порушеннями. Встановлено, що нормальну поставу мають 65,22 \% юнаків I, 52,46 \% II, 48,39 \% II та 48,39 \% IV курсів [4, 8, 11].

Окреслено тенденцію залежності особливостей рівня стану біогеометричного профрілю постави юнаків від курсу навчання (серед юнаків I курсу $18,84 \%$ осіб мають низький рівень, 18,84 \% - середній, 62,32 \% - високий), а також переважання в контингенті юнаків зі сколіотичною поставою низького рівня стану її біогеометричного профрілю $(7,69$ \% - спеціалізація "спів, хорове диригування» та спеціальність «Хореограсрія», 19,35 \% - спеціалізація «оркестров духові та ударні інструменти, народні інструменти», 50 \% - спеціалізація «фрортепіано, оркестрові, струнні інструменти») [8, 11]

Визначення рівня фрізичної підготовленості студентів мистецьких спеціальностей уможливило окреслення загальної тенденції до погіршення їхніх результатів протягом періоду на- вчання $(p<0,05)$ (рівень фрізичної підготовленості студенток досліджували на основі показників статичної силової витривалості груп м'язів тулуба).

Шляхом експертного оцінювання професійно значущих фрізичних якостей студентів спеціальності «Музичне мистецтво» різних спеціалізацій установлено, що найбільш значущою професійною фрізичною якістю для студентів спеціалізації «фрортепіано» виступає статична силова витривалість $(R=1,42)$, для студентів спеціалізації «народні інструменти» (баян) прерогативу становить статична силова витривалість $(R=1,42)$, коефріцієнт конкордації $W=0,918$, що є статистично значущим на рівні $p<0,01$.

Унаслідок експертного оцінювання професійних якостей студентів спеціальності «Музичне мистецтво» різних спеціалізацій виокремлено найбільш значущі професійні якості студентів спеціалізацій «фрортепіано» (збереження природних рухів, посидючість, $(R=1,50)$, коефріцієнт конкордації $W=0,92)$, «оркестрові струнні інструменти» (чутливість пальців, плавність, еластичність рухів пальців - скрипка, $(R=1,67)$, коефіцієнт конкордації $\mathrm{W}=0,88)$, «народні інструменти» (точність правильних відчуттів рухів (рухи руки пластичні, вільні, спрямовані на створення максимально зручного для дії пальців положення) - баян, $(R=13)$, коесріцієнт конкордації $\mathrm{W}=0,89)$.

Шляхом аналізу науково-методичної літератури та результатів констатуючого експерименту розроблено та теоретично обґрунтовано авторську концепцію ППФП студентів у процесі фізичного виховання (рис. 1)

Концептуальні основи технології ППФП студентів спеціальності «Музичне мистецтво» у процесі фрізичного виховання охоплюють мету, завдання, принципи й умови функціонування.

Мета авторської концепції полягає в теоретичному обґрунтуванні та розробленні теоретико-методичних засад ППФП майбутніх фрахівців мистецьких спеціальностей.

Для досягнення мети концепції передбачено вирішення таких завдань: виховання соціально орієнтованої особистості студента; розширення світо- 


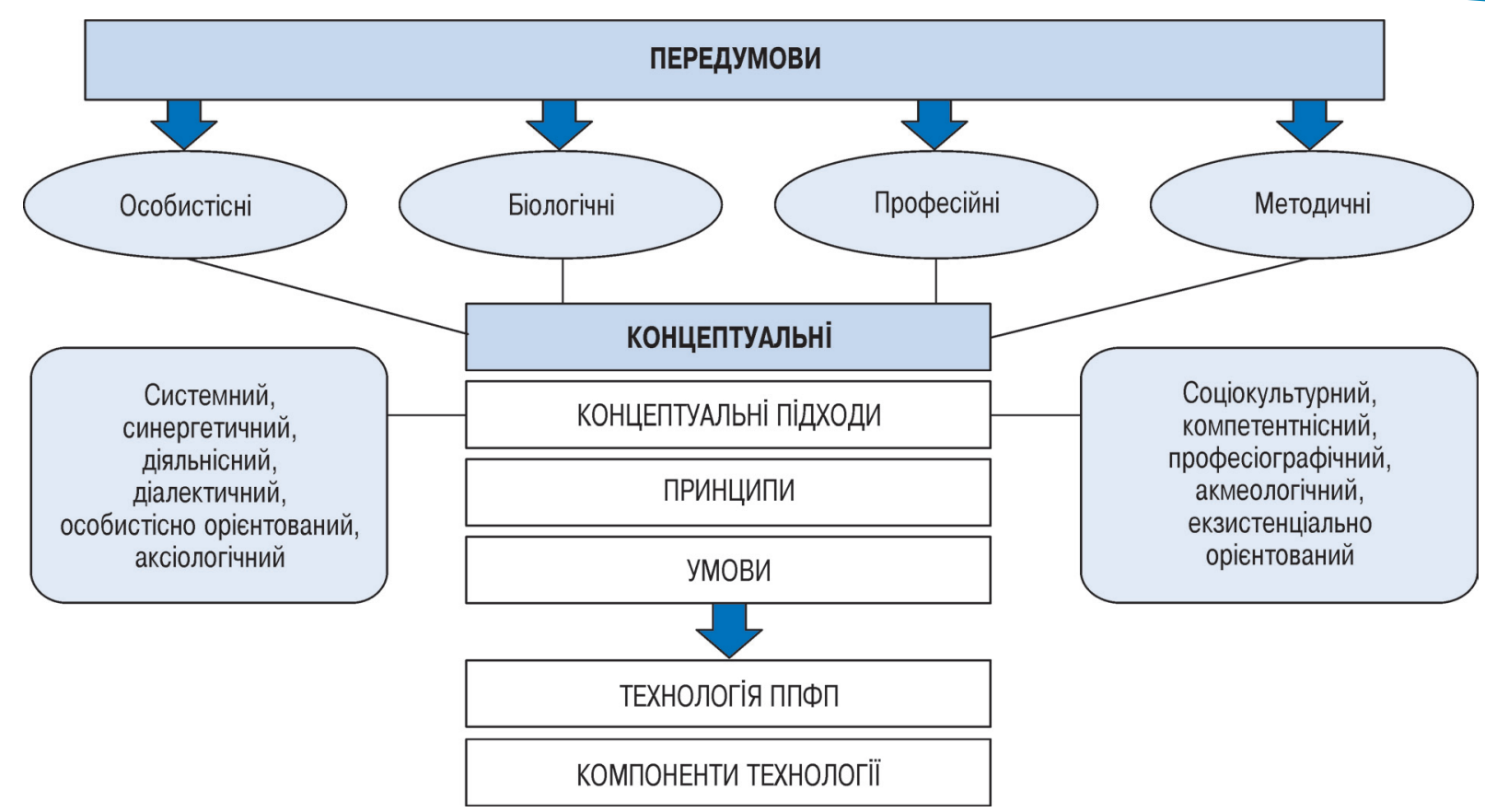

Рисунок 1 - Схема концепції професійно-прикладної фрізичної підготовки студентів спеціальності «Музичне мистецтво»

гляду студентів шляхом фрормування базової основи теоретичних знань, практичних умінь і уявлень про ЗСЖ у процесі фрізичного виховання; забезпечення засвоєння теоретичних знань і вироблення практичних умінь ППФП студентів на основі створення середовища для формування їхнього ціннісного ставлення до власного здоров'я, покращення фізичного розвитку та фізичної підготовленості; створення умов для успішного самовизначення, розвитку активної життєвої позиції та креативних здібностей студентів; створення стійких мотиваційних установок на збереження й зміцнення здоров'я; розробка та реалізація системи заходів, спрямованих на розвиток стійкої мотивації до здорового способу життя, заснованих на вільному доступі студента до інформаційного мікросередовища для забезпечення самостійної діяльності у прагненні до активного фрізичного та духовного самовдосконалення.

У межах аналізу напрацювань науковців визначено концептуальні підходи: системний, синергетичний, діяльнісний, діалектичний, особистісно орієнтований, аксіологічний, соціокультурний, компетентнісний, професіографічний, акмеологічний, екзистенціально орієнтований, які покладено в основу авторської концепції.
Основами концепції ППФП майбутніх фрахівців музичних спеціальностей у закладах освіти слугують тези про детермінованість побудови останньої потребою ринку праці у фахівцях певного профрілю; етапність її розробки; співпрацю професійного співтовариства й учасників освітнього процесу; обґрунтування змісту ППФП майбутніх фахівців музичних спеціальностей і їхніх професійно значущих якостей; упровадження отриманих характеристик у навчальний процес у вигляді технології ППФП майбутніх фахівців музичних спеціальностей у закладах освіти $[7,17]$.

Реалізацією організаційно-педагогічних умов концепції ППФП у практиці фрізичного виховання студентів є: 1) фрормування системи залучення студентів до ППФП під час навчальних занять; 2) створення умов для ППФ самопідготовки студентів у позанавчальний час; 3) інформаційнометодичне забезпечення занять; 4) підготовка викладачів до організації занять, спрямованих на ППФП; 5) розробка програми ППФП студентів [4].

Для реалізації теоретичних положень концепції ППФП студентів музичних спеціальностей у закладах освіти в дослідженні розроблено технологію ППФП майбутніх фахівців. Змістовими компонентами технології стали: мета, завдання, принципи, структурні компоненти (інформаційно-методичний, діагностично-результативний, аналітико-прогностичний, корекційно-профілактичний, критерійно-оцінювальний), етапи технології (підготовчий, основний, підтримувальний), методи, засоби й умови її практичної реалізації (організаційно-педагогічні та соціально-педагогічні), види контролю, а також критерії ефективності.

У ході розробки технології використано такі основні принципи фрізичного виховання: індивідуалізації, поступовості, системності, систематичності, доступності тощо. Методи та прийоми розвиваючого навчання спрямовані на есективний розвиток пізнавальних можливостей студентів різних музичних спеціалізацій (сприймання, мислення, музичної пам'яті, уяви), результативні за організації освітнього процесу, коли студенти самостійно або 3 допомогою викладача осмислюють матеріал, запам'ятовують, творчо оперують ним за нестандартних умов $[1,15,23]$.

Компоненти технології ППФП:

- інформаційно-методичний, що передбачав застосування програмового забезпечення, новітніх інформаційно-комунікаційних технологій, веб-сайтів закладів освіти й Інтер- 


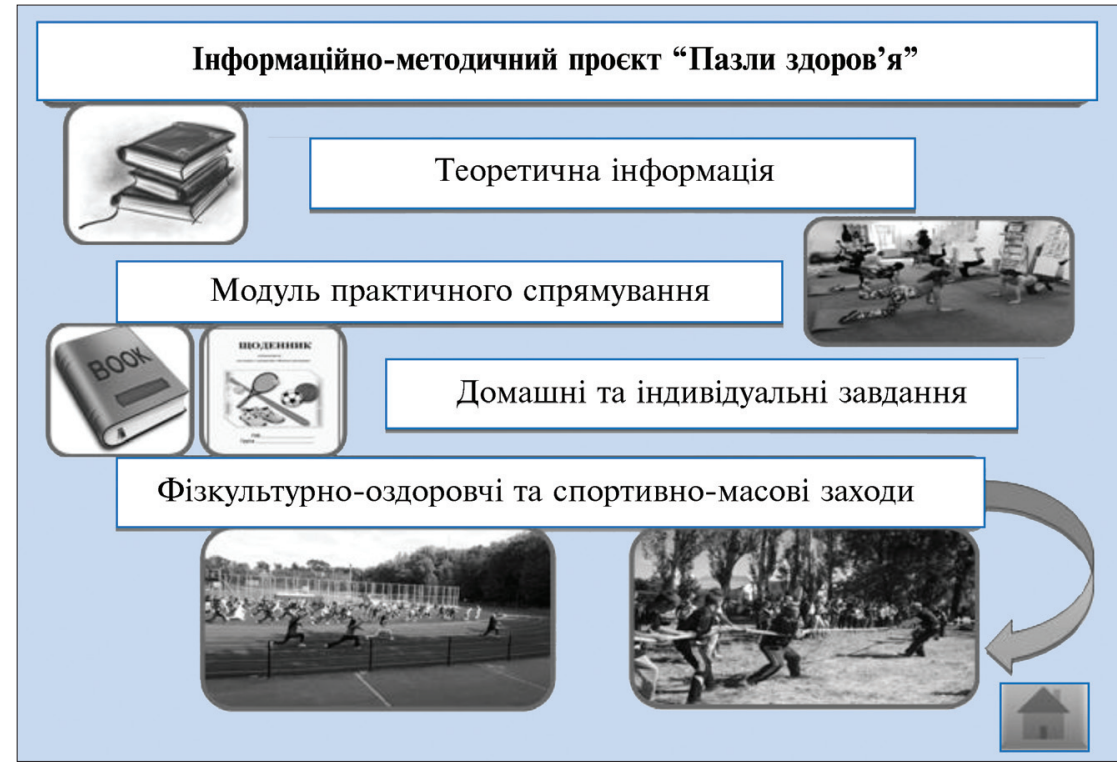

Рисунок 2 - Зображення «активного вікна» інфрормаційно-методичного проєкту «Пазли здоров'я»

нет-сервісів для підвищення ефективності та доступності теоретичного матеріалу, ефективного виконання майбутнім фахівцем професійних фрункцій;

- аналітико-прогностичний, розглянутий крізь призму отримання сучасного освітнього результату, зорієнтованого на вирішення поставлених завдань;

- корекційно-профрілактичний, пов'язаний із впровадженням корекційно-просрілактичних заходів оздоровчого спрямування, призначених для корекції ффункціональних порушень опорно-рухового апарату (ОРА) відповідно до специффіки професійної діяльності, фрізичного стану, біогеометричного профрілю постави;

- критерійно-оцінювальний, що уможливлював досягнення належної якості освітнього процесу, оптимізацію процесу формування компетентностей, порівняння якості підготовки студентів мистецьких спеціальностей.

Технологія ППФП складається з змістових модулів, які підлягали інтегруванню в освітній процес студентів освітньої програми «Музичне мистецтво» та застосуванню на всіх етапах технології.

Основою технології слугував алгоритм ППФП студентів освітньої програми спеціальності «Музичне мистецтво», профрілактика та корекція порушень їхнього біогеометричного про- філю постави, розвиток і вдосконалення професійно важливих фрізичних якостей, формування ергономіч но доцільної пози гри на інструменті із застосуванням розроблених у дослідженні комплексів модельних вправ.

Для посилення освітнього ефекту (теоретичної підготовки), формування системи теоретичних знань про ППФП з урахуванням особливостей майбутньої профресійної діяльності студентів освітньої програми «Музичне мистецтво» розроблено інформаційно-методичний проєкт (ІМП) «Пазли здоров'я» (рис. 2).

ІМП «Пазли здоров'я» сприяє формуванню пізнавальної самостійності студентів. Чітко структурований навчальний матеріал на основі визначення головного та другорядного забезпечує конкретизацію, узагальнення та розширення знань, уможливлює посилення шляхом реалізації міжпредметних зв'язків теоретичної підготовленості студентів, активізацію їхнього зацікавлення навчанням, досягнення єдності освітнього процесу та підвищення ефрективності фрізичного виховання. Проєкт складається 3 таких розділів: «Теоретична інформація», «Практичні рекомендації», «Домашні та індивідуальні завдання» [3, 4, 25, 27].

Для досягнення позитивного комплекси вправ різної дидактичної есекту ППФП осіб ЕГ розроблено спрямованості. Студенти займалися за програмами занять, що відповідали змісту авторської концепції та були інтегровані в освітню програму спеціальності «Музичне мистецтво». Зміст комплексів вправ підлягав диференціації залежно від особливостей спеціалізацій «фрортепіано, оркестрові струнні інструменти» (ЕГ1), «оркестрові духові та ударні інструменти, народні інструменти» (ЕГ2), а також структури м'язової діяльності та фоннкціональної специфріки. Фізичне навантаження добирали, зважаючи на результати попереднього рівня фрізичного стану та шляхом змін умов виконання фізичних вправ, варіювання загальної кількості повторень і тривалості виконання фрізичних вправ, зміни темпу виконання вправ з урахуванням індивідуальних особливостей організму студентів.

Для студентів ЕГ1 у 1-му півріччі застосовували комплекси вправ, спрямовані на фрормування ергономічно доцільної пози гри на інструментах (фортепіано, скрипка, альт, вілончель, арфа, домра), профрілактику порушень біогеометричного профрілю постави, що сприяє ефективності професійної діяльності, підвищенню рівня стану біогеометричного профрілю постави (вправи асиметричні та асинхронні, 3D фрітнес, комплекси вправ різної складності з використанням проффілактора Євмінова, інтегрований урок із анатомічною спрямованістю, елементи стретчингу). У 2-му півріччі, окрім перерахованих, практикували комплекси вправ дихальної гімнастики, із бодибар, колового тренування, із гантелями.

Для студентів ЕГ2 у 1-му півріччі застосовували комплекси вправ, 30рієнтовані на формування ергономічно доцільної пози гри на інструментах (флейта, гобой, кларнет, фрагот, саксофон, валторна, труба, тромбон, туба, баян, акордеон, домра, бандура), профілактику порушень біогеометричного просрілю постави, що сприяє ефективності професійної діяльності, підвищення рівня стану біогеометричного профрілю постави (комплекси вправ на корекцію порушень постави, підвищення рівня стану біогеометричного профрілю по- 
стави, комплекси вправ із гімнастичною палицею, 3D фрітнес, комплекси вправ різної складності з використанням профрілактора Євмінова, інтегрований урок із анатомічною спрямованістю, елементи стретчингу). у 2-му півріччі, окрім перерахованих, практикували комплекс вправ «Пор де бра», комплекси вправ із бодибенд, колового тренування.

Проведення після закінчення формувального експерименту повторного тестування для визначення рівня теоретичної підготовленості дало підстави стверджувати, що запропонований у межах реалізації технології комплекс заходів сприяв підвищенню рівня теоретичної підготовленості студентів, зокрема серед дівчат на тлі відсутності в ЕГ1 осіб із низьким рівнем відбулося зменшення частки осіб із середнім рівнем до 22,20 \%.Протягом експерименту зафріксовано зміни показників ІФР. Серед дівчат мистецьких спеціальностей КГ1 середній рівень мали 40,00 \% осіб на початку експерименту та 50,00 \% - наприкінці експерименту, тоді як високий рівень демонстрували 10,00 \% осіб на початку експерименту на тлі відсутності осіб із таким рівнем на його завершення; серед дівчат ЕГ1 рівень нижче за середній мали $11,11 \%$ осіб і на початку і наприкінці експерименту, середній рівень виявили 44,44 \% осіб на початку експерименту та 22,22 \% - після нього.

Наприкінці експерименту зміни типів постави юнаків спеціалізації «оркестрові духові та ударні інструменти, народні інструменти» становлять: у КГ2 нормальну поставу демонстрували лише 20,00 \% юнаків, тоді як у ЕГ2 відбулося збільшення частки юнаків із нормальною поставою до 54,55 \%.

На завершення експерименту встановлено позитивну тенденцію значень показників фрізичної підготовленості обох груп дівчат, серед яких статистично достовірно кращими виявилися результати ЕГ1 у таких тестах: «біг на 100 м, с» - на 0,52 с ( $<<0,05)$, «човниковий біг 4х9 м, с» - на 0,39 с $(p<0,05)$, «згинання-розгинання рук в упорі лежачи» - на 3,33 раза.

у ході оцінювання ефективності запропонованої технології ста- ло очевидним, що підвищення рівня фрізичної підготовленості зумовило покращення показників професійно значущих фрізичних якостей у тестах: «утримання бічного упору, с» $(\mathrm{x} \pm \mathrm{S})$ після експерименту в дівчат КГ1 $(\mathrm{X} \pm \mathrm{S})(27,50 \pm 0,43) \mathrm{c}$, у дівчат ЕГ1 $(28,67 \pm 0,50)$ с, відмінності не достовірні), «упор лежачи на передпліччях, c» $(\mathrm{x} \pm \mathrm{S})$ після експерименту в дівчат КГ1 $(43,30 \pm 1,06)$ с, у дівчат ЕГ1 $(45,44 \pm 0,88)$ с, відмінності достовірні $(p<0,05)$, «міст у положенні лежачи на спині, с» $(\mathrm{x} \pm \mathrm{S})$ після експерименту у дівчат КГ1 $(70,00 \pm 0,67)$ с, у дівчат $\mathrm{E} \Gamma 1(72,22 \pm 1,09) \mathrm{c}(\mathrm{p}<0,05)$.

Після експерименту визначення тонкорухової координації за тестом У. Г. Давлетшина дає змогу стверджувати, що юнаки КГ2 покращили результати від $\mathrm{X}=159,20$ c; $(\mathrm{S}=2,25)$ до $x=158,60$ c; $(S=2,72)$, відмінності не $€$ достовірними $(p>0,05)$, тоді як результати юнаків ЕГ2 статистично достовірно відрізняються після застосування технології від результатів на початку експерименту.

Загалом проведення експериментальних досліджень зі студентами мистецьких спеціальностей слугує підставою для констатації того, що відбулося покращення їхньої готовності до самостійних занять із ППФП, формування вміння самостійно організовувати та реалізовувати заняття, визначати ефективність останніх, підвищення рівня знань і навичок самодіагностування, самоконтролю під час занять, вироблення вміння корегувати процес ППФП. Як узагальнення отриманих результатів варто підкреслити високу ефективність розробленої концепції ППФП для студентів спеціальності «Музичне мистецтво».

Дискусія. За умов сьогодення об'єктивні передумови фрункціонування педагогічної системи охоплюють нормативно-правову базу сфрери освіти, засоби інфрормації тощо, виступають однією з причин адекватного вияву учасників освіти в ньому, можуть зазнавати змін [19, 23].

На сучасному етапі набуло значення загальноприйняте бачення ППФП як одного з напрямів фрізичної культури, що передбачає фрормування прикладних знань, фрізичних, психічних, спеціальних якостей, умінь, навичок студентів відповідно до їхньої майбутньої просесійної діяльності [10, 16], а також як системи цілей, що детермінує погодження з нею макроскопічних якостей ППФП й інших її структур $[15,16]$.

У теоретичних напрацюваннях сучасних учених [21, 22, 24] вказано, що здобуття знань стає основою для зміни свідомості студентів і визначає рівень їхніх потреб в оздоровчій руховій активності [3]. Деякі учені [15] вважають вагомим недоліком теоретичного підходу до ППФП нечіткість оперування її понятійним апаратом, а також невизначеність конкретних меж вивчення та пізнання ППФП в руслі системного підходу.

На думку Л. П. Пилипея [18], основне питання ППФП - це добір засобів фрізичної культури, що найкращою мірою сприятимуть вирішенню завдань адаптації людини до специфічних умов діяльності.

Отримані в ході констатувального експерименту дані про недостатню сфрормованість у студентів різних спеціалізацій цінніснозмістового бачення важливості здоров'я для життєдіяльності, а також потреби занять фрізичними вправами для розвитку професійно значущих фрізичних якостей увиразнюють логіку розгляду особистісних передумов дієвості певних педагогічних систем [4]. У процесі роботи доповнено зміст професійноприкладної фрізичної підготовки студентів спеціалізацій «фортепіано, оркестрові, струнні інструменти», «оркестрові духові та ударні інструменти, народні інструменти» у процесі професійно-прикладної фрізичної підготовки, види контролю, а також критерії ефективності.

Висновки. Обґрунтовано й розроблено концепцію професійноприкладної фізичної підготовки студентів спеціальності «Музичне мистецтво» спеціалізацій «фрортепіано, оркестрові, струнні інструменти», «оркестрові духові та ударні інструменти, народні інструменти», у якій визначено такі складники: соціальні, особистісні, біологічні та професійні передумови, підходи, що виступали теоретичним базисом концепції, мета 
завдання, принципи, організаційнопедагогічні й дидактичні умови, етапи впровадження, критерії ефективності та шляхи реалізації концепції.

Практичну реалізацію розробленої концепції спроєктовано на технологію професійно-прикладної фрізичної підготовки студентів спеціальності «Музичне мистецтво», яка охоплює мету, завдання, блоки цільової спрямованості, структуру та зміст занять, загальний обсяг годин і його розподіл за навчальним планом училища, інтеграцію в дисципліни професійної підготовки, перелік засобів загальної, спеціальної фрізичної підготовки, співвідношення між різними видами підготовки в рамках комплексів вправ різної спрямованості, розподіл занять із різних видів засобів технології у межах занять і критерії оцінювання фрізичного стану студентів, корекцію ергономічно доцільної пози студента спеціальності «Музичне мистецтво» під час гри на інструменті.

\section{ЛІТЕРАТУРА}

1. Андрєєва ОВ, Кашуба ВО. Пріоритетн напрями наукових досліджень ссери фрізично рекреації. Теорія і методика фрізичного вихован ня і спорту. 2011;3:31-35.

2. Асаулюк 10. Мотивація до фрізкультурнооздоровчої рухової активності як основа роз робки концепції професійно-прикладної фізич ної підготовки студентів мистецьких спе ціальностей. Вісник Східноєвропейського національного університету імені Лесі Українки 2018;(30):28-33.

3. Асаулюк I0. Теоретико-методичні осно ви професійно-прикладної фрізичної підготовки студентів мистецьких спеціальностей. Київ. 2020.

4. Асаулюк 10. Теоретико-методичні основи професійно-прикладної фізичної підготовки студентів мистецьких спеціальностей [Автореферат]. Київ. 2020. 53 с.

5. Голованова НЛ, Кашуба ВА. Информационные технологии как инструмент повышения профессионально-прикладной физической подготовки учащихся швейного произ водства. Научный потенциал молодежи - будущему Беларуси: материалы V Междунар. молодеж. науч.-практ. конф. (УО «Полесский государственный університет», г. Пинск, 31 марта 2011 г.: в 4 ч. Ч. 4. Национальный банк Peспублики Беларусь и др. Пинск: ПолесГУ, 2011. C. 199-200.

6. Єсремова А, ШестероваЛ. Обґрунтування ефективності організації та змісту посиленого курсу професійно-прикладної фрізичної підготовки студентів залізничних вищих навчальних закладів. Слобожанський науковоспортивний вісник. 2017;4(60):36-41

7. Йоркіна ЄБ. До проблеми формування професійно важливих якостей майбутніх музикантів-інструменталістів. Науковий вісник
Мелітопольського державного педагогічного університету.Серія: Педагогіка. 2011;6:113-118.

8. Кашуба В0, Асаулюк IO. Рівень стану біогеометричного профілю постави студентів в процесі фізичного виховання. Вісник Прикарпатського університету. Серія: Фізична культу pa. 2019;(34):138-145.

9. Кашуба В, Асаулюк I, Дяченко А. До питання експертного оцінювання фізичних яко стей студентів закладів освіти як передумови розробки фізкультурно-оздоровчих технологій Фізична культура, спорт та здоров'я нації. 2019;7(26):74-79.

10. Кашуба ВО, Асаулюк I0, Дяченко АA Підвищення ефективності професійно-при кладної фрізичної підготовки студентів на основ використання мультимедійних технологій. Науковий часопис НПу імені М. П. Драгоманова. 2019;1(107):25-29.

11. Кашуба В0, Асаулюк IO, Дяченко АA Стан біогеометричного профрілю постави студентів закладів освіти на сучасному етапі. Спортивний вісник Придніпров'я. 2019;2:79-87.

12. Кашуба В, Асаулюк I, Дяченко А, Миц кан Т. Особливості прояву тонкорухово координації студентів в процесі професійно прикладної фізичної підготовки. Вісник При карпатського університету. Серія: Фізична культура. 2018;(30):51-58.

13. Коновалов ИЕ. Специфика физического воспитания студентов музыкальных ССУЗ. Про фессиональное образование: модернизацион ные аспекты. Ростов-на-Дону: Издательство Международного исследовательского центра «Научное сотрудничеств0». 2013;1:69-88.

14. Кравчук ВИ. Профессионально прикладная фризическая подготовка студентов музыкальных специальностей вуза культуры и искусств: учебное пособие. Челябинск: Челя бинская гос. акад. культуры и искусств. 2014 $299 \mathrm{c}$.

15. Круцевич ТЮ, Трачук СВ, Кузнецо ва ЛІ. Фізична підготовленість юнаків коледжів різних спеціальностей. Вісник Чернігівського національного педагогічного університету. Серія: Педагогічні науки. Фізичне виховання та спорт. 2016;136:115-119.

16. Кузьменко НВ. Профессионально прикладная физическая подготовка как фактор укрепления здоровья студентов. Науковий часопис НПУ імені М. П. Драгоманова. Серія 15: Науково-педагогічні проблеми фізичної культу ри (фізична культура і спорт). 2015;6:41-44.

17. Пилипей ЛП. Професійно-прикладна фізична підготовка студентів: монографія Суми: ДВНЗ «УАБС НБУ». 2009. 314 с.

18. Пилипей ЛП. Теоретико-методичні основи професійно-прикладної фізичної підготовки студентів вищих навчальних закладів [Дисертація]. Київ. 2011. 518 с.

19. Романчук ОВ, Данилевич МВ. Особливості підготовки фахівців з фізичного вихо вання і спорту у педагогічних коледжах України Репрезентація освітніх досягнень, мас-медіа та роль фрілології у сучасній системі наук. Вінниця: Європейська наукова платформа. 2020. С. 2-10.

20. Рязанцев АА. Профессиональноприкладная фризическая подготовка студентов музыкальных вузов, исполнителей на ду ховых инструментах [Диссертация]. Москва. 2009. 140 c.

21. Футорний СМ. Теоретико-методичн основи інноваційних технологій формування здорового способу життя студентів в процесі фрізичного виховання [Авторефрерат]. Київ 2015. 44 C.
22. Юмашева ЛІ. Корекція порушень постави студентів музичного вищого навчального закладу у процесі фрізичного виховання [Автореферат]. Київ. 2007. 20 c.

23. Imas YV, Dutchak MV, Andrieieva OV, Kashuba V0, Kensytska IL, Sadovskyi 00. Modern approaches to the problem of values' formation of students' healthy lifestyle in the course of physical training. Physical education of students. 2018;22(4):9.

24. Kashuba V, Asaulyuk I, Diachenko A. The Formation of theoretical knowledge of students in the discipline of "Physical Education" in the process of professional and applied physical training $=$ Формування теоретичних знань студентів із дисципліни «Фізична культура» в процесі професійно-прикладної фрізичної підготовки. Journal of Education, Health and Sport. 2017;7(5):1054-1065. elSSN 2391-8306. http://dx.doi.org/10.5281/zenodo.2547839

25. Kashuba V0, Asaulyuk 10, Dyachenko AA. Pidvishhennya efektivnosti profesijnoprikladnoyi fizichnoyi pidgotovki studentiv na osnovi vikoristannya multimedijnikh tekhnologij. Naukovij chasopis NPU imeni M.P. Dragomanova. 2019;1(107):25-29

26. Kashuba V, Dyachenko A, Asaulyuk I. Informaczijni tekhnologiyi yak zasib pidvishhennya motivacziyi studentiv do regulyarnoyi fizichnoyi aktivnosti Information technology as a means of increasing students' motivation for regular physical activity.»Fizichna aktivnist i yakist zhittya lyudini». 2019. C. 61-62.

27. Kashuba Vitaliy, Asaulyuk Inna, Diachenko Anna. A modern view on the use of information technologiesin the process of physical education of student youth. Journal of Education, Health and Sport. 2017;7(2):765-775

\section{LITERATURE}

1. Andreieva VB, Kashuba VO. Priority directions of studies in physical recreation. Teoriia $\mathrm{i}$ metodyka fizvykhovannia i sportu. 2011;3:31-35.

2. Asauliuk 10._Motivation for physical culture and health motor activity as a basis for developing the concept of professional and applied physical training of students of art specialties. Visnyk Skhidnoievropeyskoho universytetu im. Lesi Ukrainky. 2018;(30):28-33.

3. Asauliuk 10. Theoretico-methodical bases of professional and applied physical preparation of students of art specialties. Kyiv. 2020.

4. Asauliuk 10. Theoretico-methodical bases of professional and applied physical preparation of students of art specialties. [Author's abstract]. Kyiv. 2020. 53 p.

5. Golovanova NL, Kashuba VA. Information technology as a tool for improving the professionally applied physical training of students in the sewing industry. Scientific potential of youth for the future of Belarus: materialy V Mezhdunarodnoy nauch.-prakt. konf. (UO «Polessky gosudarstvenny universitet», Pinsk, 31 March 2011. Pinsk: PolesSU, 2011. P. 199-200.

6. Yefremova A, Shesterova L._Investigation of the effectiveness of organization and the success of the advanced course of professional and applied physical training of students in the field of higher education. Slobozhanskyi naukovo-sport. visnyk. 2017;4(60):36-41.

7. Iorkina IB. To the problem of formation of professionally important qualities of future musicians-instrumentalists. Naukovyi visnyk Melitopolskoho peduniversytetu. 2011;6:113-118. 
8. Kashuba V0, Asauliuk 10. The level of the state of the biogeometric profile of students posture in the process of physical education. Visnyk Prykarpatskoho universytetu. 2019;(34): 138-145.

9. Kashuba V, Asauliuk I, Diachenko A. On the issue of expert assessment of physical qualities of students of educational institutions as a prerequisite for the development of physical culture and health technologies. Fizkultura, spoty ta zdorovia natsii. 2019;7(26):74-79.

10. Kashuba V, Asauliuk I, Diachenko A. Improving the effectiveness of professional and applied physical training of students based on the use of multimedia technologies. Naukovyi chasopys NPU imeni M. P. Drahomanova. 2019;1(107):2529.

11. Kashuba V, Asauliuk I, Diachenko A. The state of the biogeometric profile of the posture of students of educational institutions at the present stage. Sportyvnyi visnyk Prydniprovia. 2019;2:7987.

12. Kashuba V, Asauliuk I, Diachenko A Mytskan T. Peculiarities of manifestation of finemotor coordination of students in the process of professional-applied physical training. Visnyk Prykarpatskoho universytetu. 2018;(30):51-58.

13. Konovalov IE. Specifics of physical education of students of musical SSUZ. Vocational education: modernization aspects. Rostov-onDon: Izdatelstvo «Nauchnoye sotrudnichestvo». 2013:1:69-88.

14. Kravchuk VI. Professional and applied physical training of students of musical specialties of the University of Culture and Arts: a textbook. Chelyabinsk: Chelyabinskaya gos. akad. kulturi iskustv. 2014. 299 p.

15. Krutsevych T, Trachuk S, Kuznetsova L. Physical fitness of college boys of various specialties. Visnyk Chernihivskoho pedahohichnoho universutetu. 2016;136:115-119.

16. Kuzmenko NV. Professional and applied physical training as a factor of student health strengthening. Naukovyi chasopys NPU imeni M. P. Drahomanova. 2015;6:41-44.

17. Pylypey LP. Professional and applied physical training of students: treatise. Sumy: DVNZ «UABS NBU». 2009. 314 p.

18. Pylypey LP. Theoretico-methodical bases of professional and applied physical training of higher education institution students [Thesis]. Kyiv. 2011. $518 \mathrm{p}$.
19. Romanchuk OV, Danylevych MV. Peculiarities of preparing physical education and sport experts in pedagogical colleges of Ukraine. Representation of mass media education achievements and the role of philology in current system of knowledge. Vinnytsia: levropeyska naukova platforma. 2020. P. 2-10.

20. Ryazantsev AA. Professionally applied physical training of students of music universities, wind instrument performers. [Thesis]. Moscow. 2009. $140 \mathrm{p}$.

21. Futorny SM. Theoretico-methodical bases of innovation technologies for healthy life style formation in students in the course of physical education. [Author's abstract]. Kyiv. 2015. 44 p

22. lumasheva LI._Correction of posture disorders of students of music higher education in the process of physical education. [Author's abstract] Kyiv. 2007. 20 p.

23. Imas YV, Dutchak MV, Andrieieva OV Kashuba V0, Kensytska IL, Sadovskyi 00. Modern approaches to the problem of values' formation of students' healthy lifestyle in the course of physical training. Physical education of students. 2018;22(4):9.

24. Kashuba V, Asaulyuk I, Diachenko A. The Formation of theoretical knowledge of students in the discipline of «Physical Education» in the process of professional and applied physical training = Формування теоретичних знань студентів із дисципліни «Фізична культура» в процесі професійно-прикладної фрізичної підготовки. Journal of Education, Health and Sport. 2017;7(5):1054-1065. elSSN 2391-8306. http://dx.doi.org/10.5281/zenodo.2547839

25. Kashuba V0, Asaulyuk 10, Dyachenko AA. Pidvishhennya efektivnosti profesijnoprikladnoyi fizichnoyi pidgotovki studentiv na osnovi vikoristannya multimedijnikh tekhnologij. Naukovij chasopis NPU imeni M.P. Dragomanova. 2019;1(107):25-29.

26. Kashuba V, Dyachenko A, Asaulyuk I. Informaczijni tekhnologiyi yak zasib pidvishhennya motivacziyi studentiv do regulyarnoyi fizichnoyi aktivnosti Information technology as a means of increasing students' motivation for regular physical activity.»Fizichna aktivnist i yakist zhittya lyudini». 2019. C. 61-62.

27. Kashuba Vitaliy, Asaulyuk Inna, Diachenko Anna. A modern view on the use of information technologiesin the process of physical education of student youth. Journal of Education, Health and Sport. 2017;7(2):765-775

Надійшла 05.02.2021

\section{ІНФОРМАЦІЯ ПРО АВТОРІВ}

Асаулюк Інна Олексіївна https://orcid.org/0000-0001-8119-2726, innaasauliuk@gmail.com Вінницький державний педагогічний університет імені Михайла Коцюбинського 21001, Вінниця, вул. Острозького, 32

Кашуба Віталій Олександрович orcid.org/0000-0001-6669-738X, kashubavo@gmail.com Національний університет фрізичного виховання і спорту України 03150, Київ, вул. Фізкультури, 1

\section{INFORMATION ABOUT THE AUTHORS}

Asauliuk Inna https://orcid.org/0000-0001-8119-2726_innaasauliuk@gmail.com Vinnytsia State Pedagogical University named after Mykhailo Kotsiubynsky 21001, Vinnytsia, Ostroh str., 32

Kashuba Vitalii orcid.org/0000-0001-6669-738X, kashubavo@gmail.com

National University of Ukraine on Physical Education and Sport 03150, Kyiv, Fizkul'tury str., 1 